International Journal of Advanced Academic Research | Sciences, Technology and Engineering | ISSN: 2488-9849

Vol. 6, Issue 5 (May 2020)

Journal DOI: 10.46654/IJAARSTE | Article DOI: 10.46654/IJAARSTE.6221

\title{
Variations in Properties of Hydrocarbon Contaminated Soil under Bio-Wastes Treatments
}

\author{
Woyengibunugha Ere ${ }^{1}$, Grace Orlunma Chie-Amadi ${ }^{2}$ and Lloyd Godpower Amagbo* \\ ${ }^{1}$ Department of Environmental Engineering, Niger Delta University, Amasoma, Bayelsa State, \\ Nigeria. \\ ${ }^{2}$ Department of Chemical and Petrochemical Engineering, Rivers State University, P.M.B. \\ 5080, Port Harcourt, Rivers State, Nigeria.
}

*Corresponding author: Lloyd Godpower Amagbo

E-mail: amagbolloyd@gmail.com woyinse1234@gmail.com

\begin{abstract}
The physicochemical properties of crude oil polluted silt loam soil under mashed food wastes $(M F W)$ and fish wastes $(F W)$ treatment were studied. The physicochemical properties of the soil before and after pollution were analyzed in every 14 days for a total period of 56 days. The results obtained showed that there was increase in $p H$ of the soils after contamination, while there were decreases in soil moisture content, total organic carbon, nitrogen content and phosphorus content, which differ remarkably from the control samples. Therefore, this implies that the MFW and $F W$ were effective for treatment of crude oil polluted soil. Also, the restoration rate of the soil to its initial state before contamination is slightly higher with $F W$ treatment than in MFW. The differences between the physicochemical properties of control sample and samples treated with MFW and FW show the treatments will be good alternative for bioremediation of oil polluted soil.
\end{abstract}

KEYWORDS: Crude Oil, Bio-treatment, Physicochemical Properties, Contaminated Soil. 


\section{INTRODUCTION}

Soil contamination has over the years attracted global concerns, which had led to the establishment of legislations that catered for oil impacted environment (Akankali and Nwafili, 2017). Regrettably in Nigeria, improper management and weak legislations have characterized the excessive degradation of oil impacted environment in the Niger Delta region (Ejiba et al., 2016; Akankali and Nwafili, 2017). This therefore, had led to quantum of research aimed at minimizing the challenges of environmental degradation caused by crude oil exploration, production and transportation. And the degradation of the Niger Delta environment is inevitable as far as crude oil activities are continuous (Amro et al., 2013).

The discussion about crude oil pollution is an age long history that is as old as oil discovery itself. Crude oil or petroleum hydrocarbon can be harmful to organisms including man, and it is also not readily degradable under normal circumstances despite its enormous benefits (Das and Chandran, 2011; Al-Hawash et al., 2018). Some of the sources that release hydrocarbons into soil and water include oil refineries, pipelines, storage tanks and trucks designed to transport petroleum products. Most spills from these sources are aided by human errors or deliberate act. However, effects of oil pollution range from aquatic to land as well as the air. Although this study focuses on soil pollution, many studies on crude oil pollution on water environment, such as oil slick quantification and spreading have been reported (Gbigbi, 2013; Agunobi et al., 2014; Akankali and Nwafili, 2017).

The diffusion of petroleum and its fractions into soil has been extensively studied. Amro et al. (2013) investigated the penetration rate and consequences of crude oil migration in dry and wet soils. They observed that at the early stages, there was higher depth of penetration of crude oil in wet soil than in dry soil, but with time, the penetration level became more pronounced in both cases. However in the final stage, penetration of crude oil was more significantly in dry soil. Similar investigation was carried out by Khalilova (2015), to ascertain the diffusion rate of different hydrocarbon compounds in soil. He found that there was high content of total petroleum and polyaromatic hydrocarbons, asphaltenes and heavy metals in soil samples collected from various oil fields, up to $1.5 \mathrm{~m}$ depth. Khalilova further reported that the effect of hydrocarbon pollution has significantly impacted on the soil biological properties due to longterm anthropogenic activities, which reduced the self-purification capacity of the soil.

When soil is contaminated by oil, it affects the properties which support plant growth, and also, increase the tendency of groundwater contamination (Adams et al., 2014). Although, most hydrocarbon pollutants may naturally degrade due to the natural properties of soil, such as selfpurification capacity, whereas, others may not (Khalilova, 2015).

Following extensive studies on crude oil as pollutant, either via laboratory or on-site investigation, several limiting factors have been identified as affecting the biodegradation of petroleum hydrocarbons (Das and Chandran, 2011). Thus, a comprehensive understanding of the mechanisms and factors affecting biodegradation will help in making the best choice for bioremediation strategy (Sihag et al., 2014). According to Adams et al. (2015), selection of a 
bioremediation technology depends on site specific requirements, which are crucial for effective remedial process. Das and Chandran (2011) reported that composition and innate biodegradability of petroleum hydrocarbon pollutant should be of primary importance consideration when assessing a suitable remediation approach for crude oil.

Factor such as temperature is a key parameter in bioremediation of petroleum hydrocarbon. It can directly affect the chemistry of pollutant, physiology and diversity of the microbial flora (Das and Chandran, 2011). Thus, at low temperatures, oil viscosity would increase, reducing the volatility of toxic low molecular weight hydrocarbons, thereby minimizing enzymatic activities necessary to cause accelerated biodegradation (Bisht et al., 2015). Temperature also affects the solubility of hydrocarbons, and the rate of biodegradation generally decreases with decreasing temperature, but at elevated temperature, solubility of hydrocarbon will increase, while the viscosity will decrease (Aislabie et al., 2006; Okoh, 2006).

Nutrient is another important factor that influences the success of biodegradation process of hydrocarbon pollutants. Thus, bioremediation has proven to be an effective method for clean-up of oil contaminated soil through the application of nutrients (Adaba, 2013). Hesnawi and Adbeib (2013) equally showed that nutrients addition promote biodegradation of contaminants in contaminated environment. Nutrients such as nitrogen, phosphorus, and many others are sources of energy for microorganisms when they feed on them, thereby enhancing the biodegradation processes (Das and Chandran, 2011). Though, excessive nutrient concentrations can also inhibit biodegradation activity (Chaillan et al., 2006).

The $\mathrm{pH}$ of the remediating environment is an influential property for bioremediation process. Environmental $\mathrm{pH}$ affects cell membrane transport and catalytic reaction balance as well as enzyme activities (Bonomo et al., 2001). Most of the heterotrophic bacteria prefer to grow in a neutral to alkaline $\mathrm{pH}$ in contrast to the $\mathrm{pH}$ of the most aquatic ecosystems (Bartha and Bossert, 1984). Pawar (2015) observed that soil $\mathrm{pH}$ of 7.5 was most convenient for the degradation of petroleum hydrocarbons. In Das and Chandran (2011), microorganisms activities can be optimum in $\mathrm{pH}$ range between 6 and 9.

Other soil properties that influence the degradation of contaminants in soil environment include; total organic carbon, moisture content, soil type and contact time, etc. Different soils exhibit distinct characteristics in bioremediation of crude oil (Umeda et al., 2018). Soil with low water holding capacity, low total organic carbon content, or surface area may create impediment for the growth of microorganisms (Youdeowei, 2012; Adaba, 2013). Although, many bioremediation factors could be in very favourable conditions for effective remediation process, but if enough contact time is not given, the remediation target may not be realizable. Adams $e t$ al. (2015) stated that the duration of treatment exposure in contaminated environment will enhance bioremediation.

Bioremediation uses microbial metabolism in favourable environmental conditions and sufficient nutrients to breakdown contaminants like petroleum hydrocarbons. Microorganism 
used for bioremediation can be cultured from plants and animal sources and then introduced directly into the polluted system or, the microorganism source is introduced into the polluted system as nutrient stimulant, thereby energizing the microorganisms in the system to grow or populate as the plant or animal source decays over time. The various techniques for microbial culture and application in bioremediation processes of contaminated soil have been outlined in the review by Yuniati (2018).

Akpe et al. (2015) reported that high concentration of crude oil was removed from soil treated with cassava peels, and this was due to availability of nutrients like nitrogen, potassium, phosphorus and organic carbon in cassava peels. However, the availability of bioremediation stimulator in soil amendment had been emphasized by Ukpaka (2016), while investigating moringa leave extract for remediation of crude oil in polluted land. He observed that the presence of component like phosphates, potassium and nitrogen in moringa leave extract, were useful as they energized the activities of microorganism required to accelerate bioremediation process. Therefore concluded that moringa leave extract enhanced the remediation of crude oil and rehabilitated the polluted land, thereby reinstating the soil constituents for agricultural purposes.

Again, in a bid to remediating agricultural soil for improved nutrients, Ukpaka and Nkakini (2017) investigated the performance of three different treatment formulations namely dried poultry manure, dried goat dung and fine sawdust, which showed excellent ability in degradation of crude oil in agricultural soil, thereby improving the soil nutrients and as well, the yield of agricultural produce. In the study by Ere and Amabo (2019), improvement in physicochemical properties of soil was pointed as reason for high biodegradation efficiency recorded for soil with treatment as compared to sample with no treatment.

Large quantities of food and fish wastes are generated in homes daily, and discarded with views that they have no usefulness benefits. As to make these wastes useful, this study explored the utilisation of food and fish wastes for bioremediation of crude oil polluted soil by investigating the physicochemical properties of the polluted soil under mashed food wastes (MFW) and fish wastes (FW).

\section{MATERIALS AND METHODS}

\subsection{Collection of Samples}

The soil sample was collected from Enito II Village in Ahoada West Local Government Area of Rivers State, Nigeria. The choice of the location for soil collection was based on the fact that Enito II village is one of the communities that host oil and gas multinational companies, which often is affected by crude oil pollution from crude oil facilities. The soil was collected between $10 \mathrm{~cm}$ and $30 \mathrm{~cm}$ depth. The food and fish wastes were gathered from different households in same Enito II village. The food wastes, which include yam, cassava, plantain and banana peels were mashed together. The mashed food wastes were labelled MFW. Similarly, the fish wastes, 
which include intestine, gills, fins and scales were mashed together and labelled FW. Crude oil sample was collected by permission from a licensed Oil and Gas Company in Rivers State.

\subsection{Experimental Procedure}

$600 \mathrm{~g}$ of soil samples were weighed into different plastic containers. The weighed samples were contaminated with $100 \mathrm{ml}$ of crude oil. The mixture was properly mixed for uniform concentration, and left for three days to stabilize. Thereafter, $100 \mathrm{~g}$ of the prepared MFW and FW were separately added into each of the container with samples. Another sample with only soil and crude oil, called control sample was prepared. Every two days, the content of the containers was stirred to ensure uniform distribution of the treatment concentration. Every fourteen (14) days, $10 \mathrm{~g}$ weighed sample from each container were collected and subjected to laboratory analysis to determine the $\mathrm{pH}$, moisture content, total organic carbon, nitrogen and phosphorus content.

\subsubsection{Soil pH}

The $\mathrm{pH}$ of the soil samples were determined using Hanna HI $2211 \mathrm{pH} / \mathrm{ORP}$ meter.

\subsubsection{Moisture Content}

The moisture content of the samples was determined according to standard method described by Ayotamuno et al. (2011). 10g of soil sample was weighed into a crucible and heated in an oven at $105^{\circ} \mathrm{C}$ for 24 hours to dry off water content in the soils. After which, the dried soil samples were cooled in desiccator for 30 minutes. On cooling, the samples were reweighed to obtain a constant weight. However, to calculate the percentage moisture content, the following equation was used:

$$
\operatorname{MC}(\%)=\frac{w_{1}-w_{2}}{w_{1}} \times 100 \%
$$

Where $M C=$ Moisture content $(\%), w_{1}=$ Initial weight of soil sample $(\mathrm{g})$ and $w_{2}=$ Weight of dried soil sample $(\mathrm{g})$.

\subsubsection{Total Organic Carbon}

Total Organic Carbon (TOC) was determined using the method described by Umeda et al. (2017). 1.0g of crushed fine representative soil sample was weighed in duplicate into $250 \mathrm{ml}$ beaker. $10 \mathrm{ml}$ of potassium dichromate solution was pipetted into beakers and then, rotated gently to completely wet the soil sample, and then, followed by addition of $20 \mathrm{ml}$ of concentrated $\mathrm{H}_{2} \mathrm{SO}_{4}$ using an automatic pipette, directing the stream into the suspension. Thereafter, the beaker was gently rotated to obtain a uniform mixture of soil and reagents, and vigorously rotated for the next one minute, for effective and more complete oxidation, before being allowed to stand for 30 minutes on sheet of asbestos. On settling, $100 \mathrm{ml}$ of distilled water was added followed by addition of 3-4 drops of $0.5 \mathrm{ml}$ diphenylamine indictor. The solution was titrated with $0.5 \mathrm{~N}$ ferrous sulfate solution. The end point was noticed as dull green through turbid blue to brilliant green. The process was repeated on distilled water (blank titration), but 
without soil to standardize the dichromate. The TOC was calculated according to the following formula.

$$
\text { TOC }=\text { Blank }-\frac{\text { volumeof soil sample titre } \times 0.195}{\text { weight of soil sample }} \times 100 \%
$$

\subsubsection{Total Nitrogen}

Total nitrogen content was determined according to APHA (1998) method. The percentage of nitrogen in soil was calculated according to the following equation.

$$
N(\%)=\frac{(T-B) \times N \times 1400}{S} \times 100 \%
$$

Where: $\mathrm{T}=$ Sample Titration (ml), $\mathrm{B}=$ Blank Titration (ml), $\mathrm{N}=$ Normality of $\mathrm{H}_{2} \mathrm{SO}_{4}$ and $\mathrm{S}=$ Sample weight $(\mathrm{mg})$.

\subsubsection{Phosphorous Content}

Phosphorus content was determined according to APHA (1998) method.

\section{RESULTS AND DISCUSSION}

\subsection{Response of soil physicochemical properties under treatment}

The behaviour of the polluted soils after application of the treatments over the investigative period was studied via the soil physicochemical properties. Table 1 showed the initial properties of soil before contamination with crude oil.

Table 1: Physicochemical characteristics of soil before contamination

\begin{tabular}{ll}
\hline Parameters & Value \\
\hline Temperature $\left({ }^{\circ} \mathrm{C}\right)$ & 27 \\
$\mathrm{pH}$ & 6.46 \\
Moisture content $(\%)$ & 33.37 \\
TOC $(\%)$ & 1.14 \\
Nitrogen content $(\%)$ & 2.12 \\
Phosphorus content $(\mathrm{mg} / \mathrm{kg})$ & 2.23 \\
TPH $(\mathrm{mg} / \mathrm{kg})$ & 7.73 \\
Porosity & 0.673 \\
Bulk Density $\left(\mathrm{g} / \mathrm{cm}^{3}\right)$ & 1.22 \\
Sand $(\%)$ & 21.54 \\
Silt $(\%)$ & 63.08 \\
Clay $(\%)$ & 15.38 \\
\hline
\end{tabular}

Table 1 shows the physicochemical properties of soil before being contaminated with crude oil. The temperature, $\mathrm{pH}$, moisture content (MC), total organic carbon (TOC), nitrogen content (NC) and phosphorus content (PC) of the soil were initially analysed as presented in Table 1. Obviously, the TPH content in the various soils was very low compared to $50 \mathrm{mg} / \mathrm{kg}$ maximum permissible limit set by DPR (DPR, 2002). Also, the soils' porosity and bulk density were 
measured. Finally, the particle size distribution (PSD) analysis of the soil showed that the soil has $21.54 \%$ sand, $63.08 \%$ silt and $15.38 \%$. Therefore, it is classified as silt loam soil.

\subsubsection{Influence of treatment on soil pH}

Table 2: Variations in soil pH

\begin{tabular}{llll}
\hline Time (Days) & Control & MFW & FW \\
\hline 0 & 6.46 & 6.46 & 6.46 \\
14 & 5.29 & 6.15 & 6.24 \\
28 & 5.85 & 6.78 & 6.84 \\
42 & 6.05 & 6.81 & 6.95 \\
56 & 6.23 & 6.97 & 7.03 \\
\hline
\end{tabular}

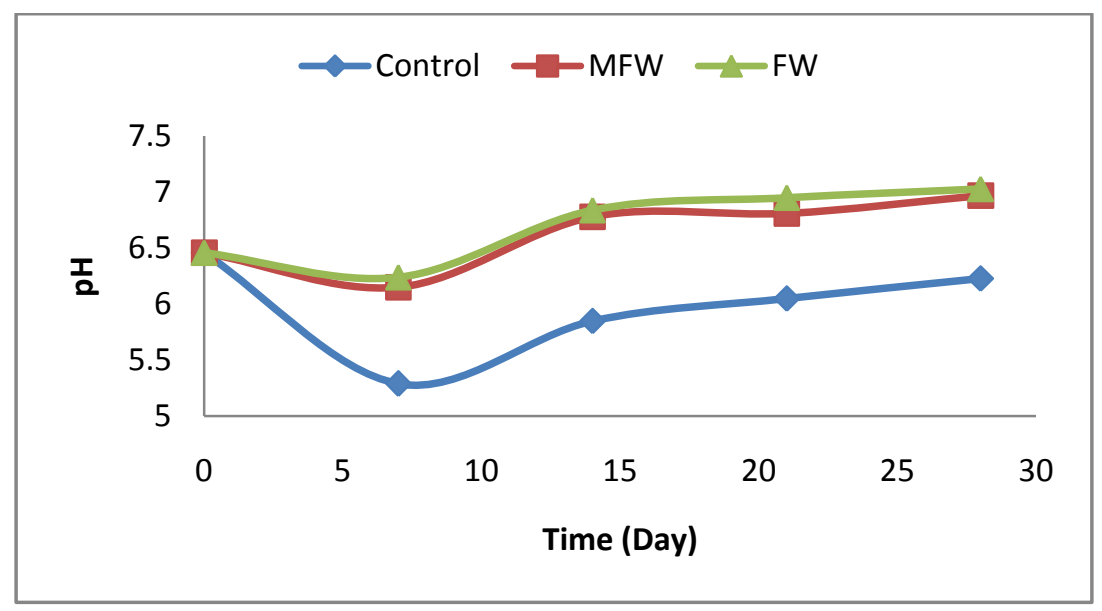

Figure 1: Variation of $\mathrm{pH}$ with time

Figure 1 shows the $\mathrm{pH}$ profiles of the various treatment options with time. Obviously, there were changes from the initial condition of the soil. Thus, the $\mathrm{pH}$ of the soil dropped from its initial value after the introduction of the crude oil. The changes in physicochemical properties of soil after the addition of crude oil have equally been reported by some researchers (Ayotamuno et al., 2006 and Azubuike et al., 2016). The soil $\mathrm{pH}$ after pollution decreased from its initial condition of 6.46 to 5.29 in control sample, 6.15 in MFW sample and 6.24 in FW sample after 14 days of treatment. But there were gradual increase in $\mathrm{pH}$ from the $14^{\text {th }}$ day. Hence, at the $56^{\text {th }}$ day of analysis, $\mathrm{pH}$ increased to 6.23 in control sample, 6.97 in sample treated with MFW and 7.03 in sample treated with FW. However, the increase in $\mathrm{pH}$ for control sample was low compared to the samples with treatment. The increase in $\mathrm{pH}$ in soil treated with FW was higher than that of MFW. 


\subsubsection{Influence of treatment on soil moisture content}

Table 3: Variations in moisture content

\begin{tabular}{llll}
\hline Time (Days) & Control (\%) & MFW (\%) & FW (\%) \\
\hline 0 & 33.37 & 33.37 & 33.37 \\
14 & 27.16 & 23.83 & 23.29 \\
28 & 24.98 & 20.35 & 19.12 \\
42 & 21.14 & 17.22 & 16.33 \\
56 & 17.88 & 15.15 & 14.67 \\
\hline
\end{tabular}

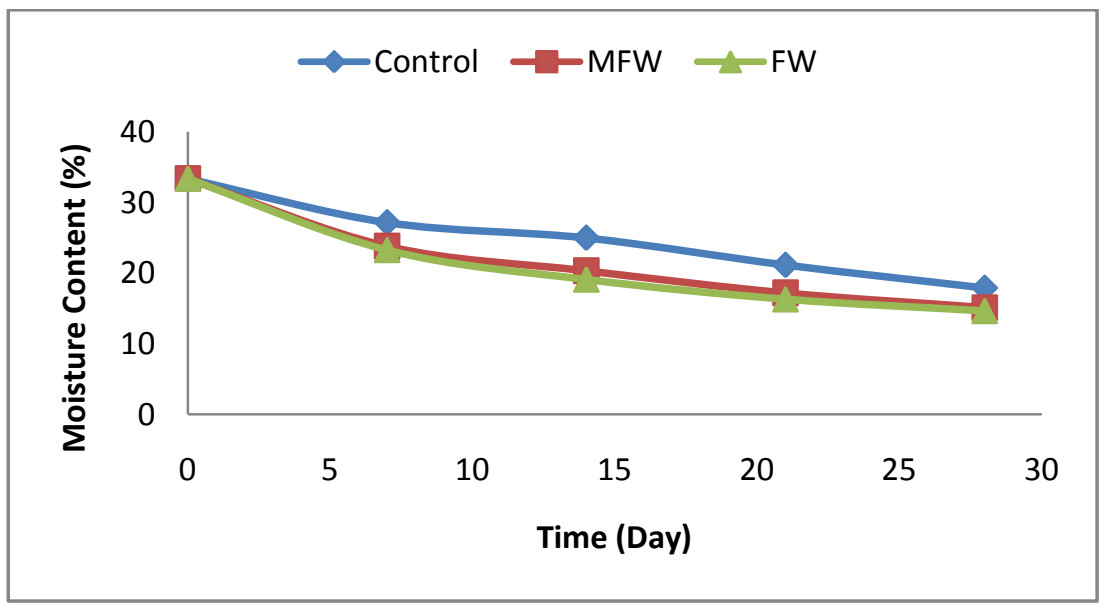

Figure 2: Variation of Moisture Content with time

Figure 2 shows the variation of moisture content with time. The moisture content decreases with time for both control and treated samples. The moisture content decreased from initial $33.37 \%$ to $17.88 \%$ in control sample, $15.15 \%$ in sample treated with MFW and $14.67 \%$ in sample FW. The soil with no treatment recorded high amount of moisture content than the treated soil samples. The trends in moisture content are similar to the previous studies (Umeda et al., 2017).

\subsubsection{Influence of treatment on soil total organic carbon}

Table 4: Variations in TOC

\begin{tabular}{llll}
\hline Time (Day) & $\begin{array}{l}\text { Control } \\
(\mathbf{m g} / \mathbf{k g})\end{array}$ & $\begin{array}{l}\text { MFW } \\
(\mathrm{mg} / \mathrm{kg})\end{array}$ & $\begin{array}{l}\text { FW } \\
(\mathrm{mg} / \mathrm{kg})\end{array}$ \\
\hline 0 & 1.14 & 1.14 & 1.14 \\
14 & 1.17 & 1.06 & 1.07 \\
28 & 1.12 & 1.03 & 1.01 \\
42 & 1.08 & 0.97 & 0.94 \\
56 & 1.06 & 0.95 & 0.92 \\
\hline
\end{tabular}




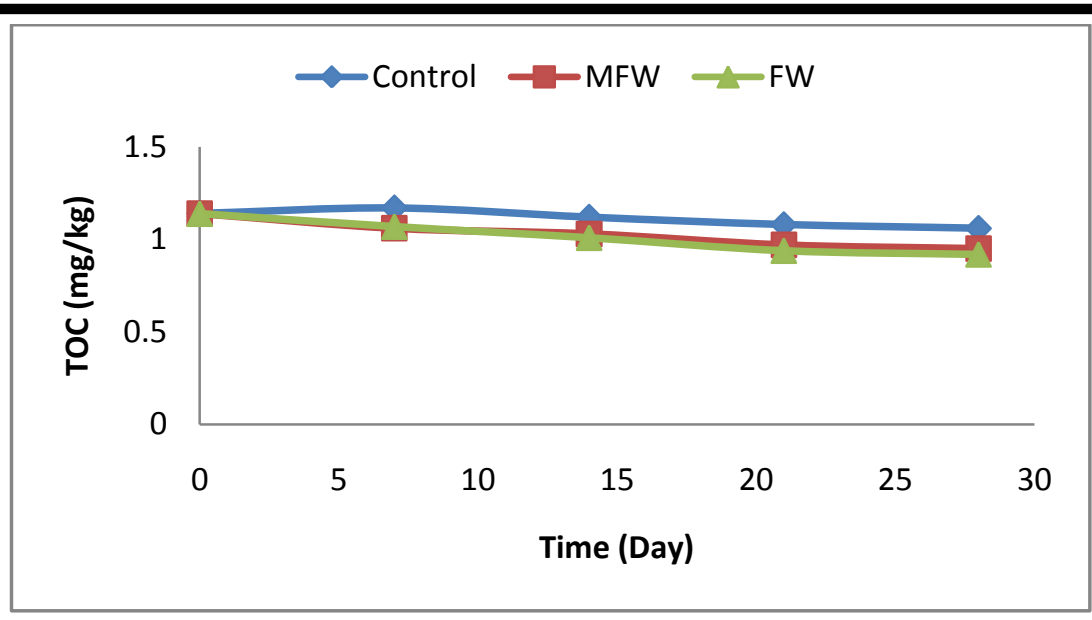

Figure 3: Variation of TOC with time

Like the soil moisture content, the total organic carbon decreases with time. However, the TOC in the control samples was higher than samples with treatment. The TOC in soil before pollution was $1.14 \mathrm{mg} / \mathrm{kg}$, but at the end of the investigation, it decreased to $1.06 \mathrm{mg} / \mathrm{kg}$, $0.95 \mathrm{mg} / \mathrm{kg}$ and $0.92 \mathrm{mg} / \mathrm{kg}$ in control, MFW and FW treatment samples respectively. Again, the control sample recorded the highest concentration of TOC. This scenario was as a result of biodegradation activities taking place in the treatment samples. The trend of TOC over the investigation period was further demonstrated in Figure 3. TOC level in the soil amended with FW treatment slightly edged that of MFW treatment.

\subsubsection{Influence of treatment on soil nitrogen content}

Table 5: Variations in nitrogen content

\begin{tabular}{llll}
\hline Time (Days) & $\begin{array}{l}\text { Control } \\
(\mathbf{m g} / \mathbf{k g})\end{array}$ & $\begin{array}{l}\text { MFW } \\
(\mathrm{mg} / \mathrm{kg})\end{array}$ & $\begin{array}{l}\text { FW } \\
(\mathrm{mg} / \mathrm{kg})\end{array}$ \\
\hline 0 & 2.12 & 2.12 & 2.12 \\
14 & 1.17 & 2.73 & 3.09 \\
28 & 1.04 & 1.61 & 1.75 \\
42 & 1.01 & 0.25 & 0.42 \\
56 & 0.99 & 0.12 & 0.17 \\
\hline
\end{tabular}

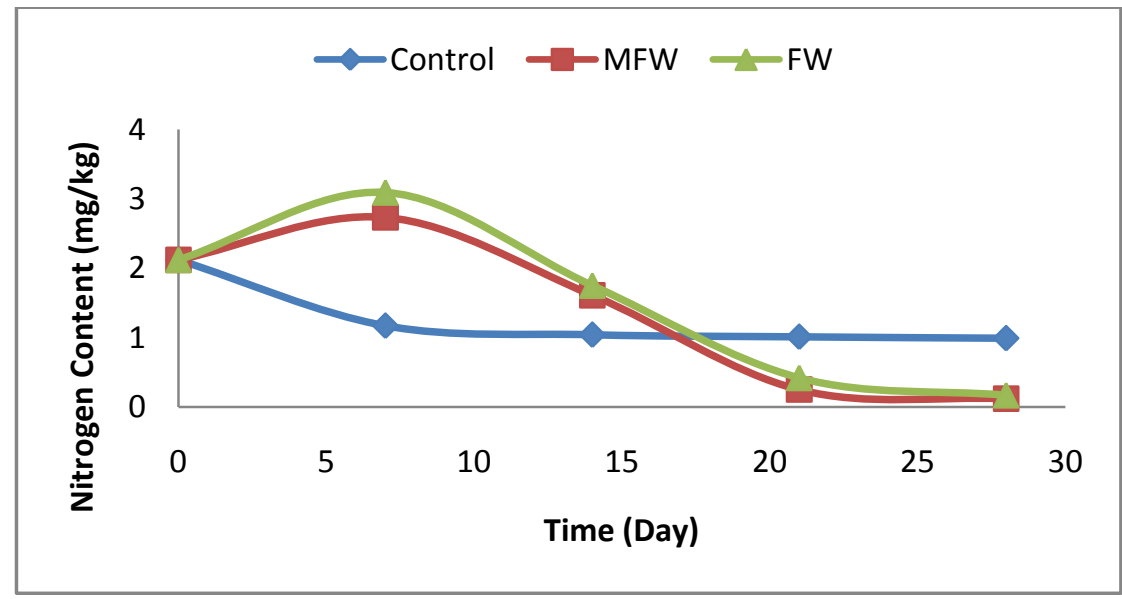

Figure 4: Variation of nitrogen content with time 
Variation in nitrogen content in the soil over the investigation period is shown in Figure 4. Thus, nitrogen content initially increased up to the $14^{\text {th }}$ day for samples with treatment, and decreased gradually until the end of the investigation. This increase in nitrogen content within the first $14^{\text {th }}$ day was because of the addition of treatment, which improves nitrogen as stimulating agents for biodegrading bacteria (Al-Hawash et al., 2018). Again, FW produced more nitrogen than the MFW. However, the nitrogen content in the soil before pollution was $2.12 \mathrm{mg} / \mathrm{kg}$, but at $56^{\text {th }}$ day, it decreased to $0.99 \mathrm{mg} / \mathrm{kg}(53.30 \%$ reduction), $0.12 \mathrm{mg} / \mathrm{kg}(94.34 \%$ reduction) and $0.17 \mathrm{mg} / \mathrm{kg}(91.98 \%$ reduction) in control, MFW treatment and FW treatment samples respectively. The percentage reduction in nitrogen content at the $56^{\text {th }}$ day was highest in soil treated with MFW, but at other days, it lowered than those of FW.

\subsubsection{Influence of treatment on soil phosphorus content}

Table 6: Variations in phosphorus content

\begin{tabular}{llll}
\hline Time (Days) & $\begin{array}{l}\text { Control } \\
(\mathrm{mg} / \mathrm{kg})\end{array}$ & $\begin{array}{l}\text { MFW } \\
(\mathrm{mg} / \mathrm{kg})\end{array}$ & $\begin{array}{l}\text { FW } \\
(\mathrm{mg} / \mathrm{kg})\end{array}$ \\
\hline 0 & 2.23 & 2.23 & 2.23 \\
14 & 1.22 & 3.07 & 3.31 \\
28 & 1.19 & 1.13 & 1.49 \\
42 & 1.18 & 0.78 & 0.86 \\
56 & 1.16 & 0.53 & 0.77 \\
\hline
\end{tabular}

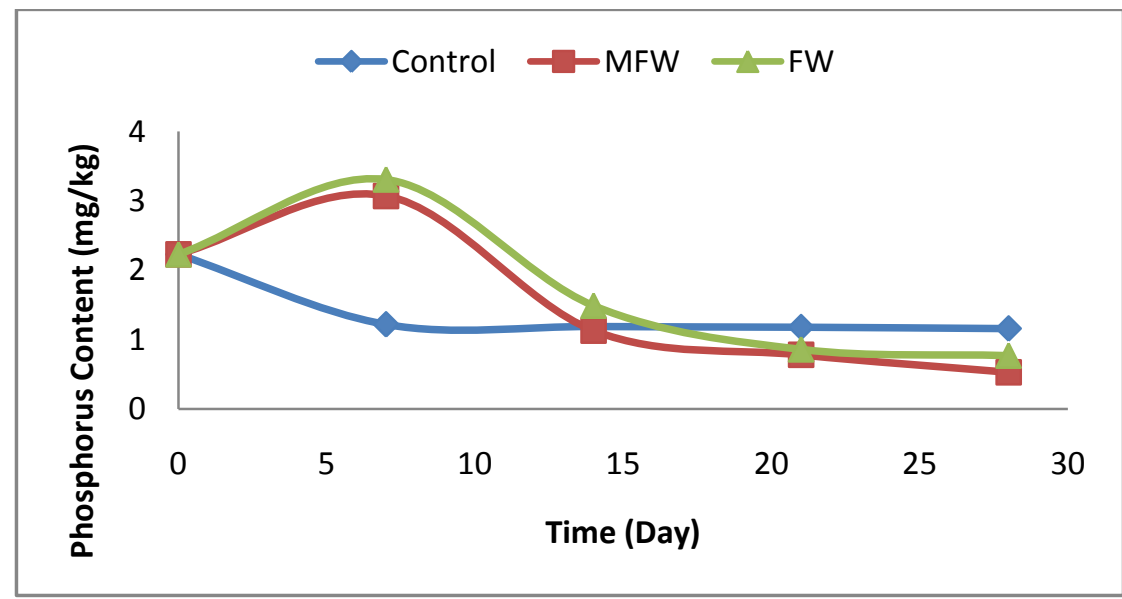

Figure 5: Variation of phosphorus content with time

The variation in phosphorus content in the soil is shown in Figure 5. Like nitrogen, phosphorus content with treatment initially increased within the first 14 days, and thereafter, decreased with time. Again, like in nitrogen content, the initial increase in phosphorus content was not observed in the control sample because no treatment was added. Thus, phosphorus content in the soil before pollution was $2.23 \mathrm{mg} / \mathrm{kg}$, but at the $56^{\text {th }}$ day, it decreased to $1.16 \mathrm{mg} / \mathrm{kg}(47.98 \%$ reduction), $0.53 \mathrm{mg} / \mathrm{kg}(76.23 \%$ reduction) and $0.77 \mathrm{mg} / \mathrm{kg}$ (65.47\% reduction) in control, MFW treatment and FW treatment samples respectively. Again, there was higher percentage reduction, in phosphorus content in soil treated with FW than those treated with MFW, and because of the higher content of phosphorus nutrient, hydrocarbon degrading bacteria would be most populated in soil with FW (Al-Hawash et al., 2018). 


\section{CONCLUSION}

The physicochemical properties of the soil treated with mashed food and fish wastes show variations from the control samples. Thus, there was increase in $\mathrm{pH}$ of soil after contamination and decrease in the soil moisture content, total organic carbon, nitrogen and phosphorus content, which implied that there was improvement in the soil due to treatment application. This indicates that the MFW and FW as treatment for bioremediation would be effective in removing hydrocarbon contaminants from soil. Also, the restoring rate of the soil to its initial state before contamination is slightly higher with FW treatment than in MFW, which also implied that higher degradation would be achieved with FW treatment. 


\section{REFERENCES}

Adaba, C. S. (2013). Effects of Particle Size Distribution on Bioremediation of Crude Oil Polluted Sandy Soils, Nigerian Journal of Technology, 32(3), 435-439.

Adams, G.O., Tawari-Fufeyin, P. \& Igelenyah, E. (2014). Bioremediation of Spent Oil Contaminated Soils Using Poultry Litter, Research Journal in Engineering and Applied Science 3(2) 124-130.

Adams, G.O., Tawari-Fufeyin, P., Okoro, S.E. \& Igelenyah, E. (2015). Bioremediation, Biostimulation and Bioaugmention: A Review, International Journal of Environmental Bioremediation \& Biodegradation, 3(1), 28-39.

Agunobi, K. N., Obienusi, E. A. \& Onuoha, D. C. (2014). An Investigation of the Pattern and Environmental Impact of Oil Spillage in Etche Local Government Area of Rivers State, Nigeria, Journal of Natural Sciences Research, 14(16), 124-137.

Aislabie, J., Saul, D. \& Foght, J. (2006). Bioremediation of Hydrocarbon-Contaminated Polar Soils, Extremophiles, 10, 171-179.

Akankali, J. A. \& Nwafili, S. A. (2017). An Assessment of the Socioeconomic Impact of Crude Oil Pollution on Aquaculture in Gokana Local Government Area Rivers State, Nigeria, Nigerian Journal of Fisheries and Aquaculture 5(1), 87-94.

Akpe, A.R., Ekundayo, A.O., Aigere, S.P. \& Okwu, G.I. (2015). Bacterial Degradation of Petroleum Hydrocarbons in Crude Oil Polluted Soil Amended with Cassava Peels, American Journal of Research Communication, 3(7), 99-118.

Al-Hawash, A.B., Dragh, M.A., Li, S., Alhujaily, A., Abbood, H.A., Zhang, X. \& Ma, F. (2018). Principles of Microbial Degradation of Petroleum Hydrocarbons in the Environment, Egyptian Journal of Aquatic Research, 44, 71-76.

American Public-Health Association (APHA) (1998). Standard Methods for the Examination of Water and Wastewater $\left(20^{\text {th }}\right.$ Edition), Washington DC: APHA.

Amro, M. M., Benzagouta, M. S. \& Karnanda, W. (2013). Investigation on Crude Oil Penetration Depth into Soils, Arabian Journal of Geosciences, 6(3), 873-880.

Ayotamuno, M.J., Kogbara, R.B. \& Agunwamba, J.C. (2006).Bioremediation of a Petroleum Hydrocarbon Polluted Agricultural Soil at Various Level of Soil Tillage in Port Harcourt, Nigeria Journal of Technology, 25, 44-51.

Ayotamuno, M.J., Okparanma, R.N. \& Amadi, F. (2011).Enhanced Remediation of Oil Sludge with Saline Water, African Journal of Environmental Science and Technology, 5(4), 262-267.

Azubuike, C.C., Chikere, C.B. \& Okpokwasili, G.C. (2016). Bioremediation TechniquesClassification Based on Site of Application: Principles, Advantages, Limitations and Prospects, World Journal of Microbiology and Biotechnology, 32,180-197.

Bartha, R. \& Bossert, I. (1984). The Treatment and Disposal of Petroleum Wastes, New York, USA: Macmillan.

Bisht, S., Pandey, P., Bhargava, B., Sharma, S., Kumar, V. \& Sharma, K.D. (2015). Bioremediation of Polyaromatic Hydrocarbons (PAHs) using Rhizosphere Technology, Brazilian Journal of Microbiology, 46 (1), 7-21. 
Bonomo, R., Cennamo, G., Purrello, R., Santoro, A. \& Zappala, R. (2001). Comparison of three Fungal Laccases from Rigidoporus Lignosus and Pleurotus Ostreatus: Correlation between Conformation Changes and Catalytic Activity, Journal of Inorganic and Biochemical, 83(1), 67-75.

Chaillan, F., Cha^neau, C.H., Point, V. Saliot, A. \& Oudot, J. (2006). Factors Inhibiting Bioremediation of Soil Contaminated with Weathered Oils and Drill Cuttings,

Das, N. \& Chandran, P. (2011). Microbial Degradation of Petroleum Hydrocarbon Contaminants: An Overview, Biotechnology Research International, 4(6), 810-822.

Department of Petroleum Resources (DPR) (2002). Environmental Guidelines and Standards for the Petroleum Industry in Nigeria (EGASPIN), Ministry of Petroleum and Natural Resources, Abuja, Nigeria.

Ejiba, I. V., Onya, S. C. \& Adams, O. K. (2016). Impact of Oil Pollution on Livelihood: Evidence from the Niger Delta Region of Nigeria, Journal of Scientific Research \&

Ere, W. \& Amagbo, L.G. (2019). Degradation Efficiency of Spent Mushroom in Petroleum Contaminated Soil, International Journal of Advanced Academic Research, 59(3), 1723.

Gbigbi, T. M. (2013). Fishing in Oil Spillages Zone: A Case Study of Burutu Local Government Area of Delta State, Nigeria, African Journal of Agricultural Research, 8(16), 1563-1569.

Hesnawi, R.M. \& Adbeib, M.M. (2013). Effect of Nutrient Source on Indigenous Biodegradation of Diesel Fuel Contaminated Soil, Apcbee Procedia, 5, 557-561.

Khalilova, H. K. (2015). The Impact of Oil Contamination on Soil Ecosystem, Journal of Biological and Chemical Research, 3, 133-139.

Lawal, O.M. \& Nwokem, N.C. (2017). Removal of Oil from Crude Oil Polluted Water Using Mango Seed Bark as Sorbent in a Packed Column, Federal University Wukari Trends in Science \& Technology Journal, 2(2), 973-975.

Okoh, A.I. (2006). Biodegradation Alternative in the Cleanup of Petroleum Hydrocarbon Pollutants, Biotechnology and Molecular Biology Review, 1(2), 38-50.

Pawar, R.M. (2015). The Effect of Soil pH on Bioremediation of Polycyclic Aromatic Hydrocarbons (PAHS), Journal of Bioremediation \& Biodegradation, 6(291), 23-44.

Reddy, K.R. (2002). Engineering Properties of Soils Based on Laboratory Testing, Department of Civil and Material Engineering, University of Illinois, Chicago.

Sihag, S.., Pathak, H. \& Jaroli, D.P. (2014). Factors Affecting the Rate of Biodegradation of Polyaromatic Hydrocarbons, International Journal of Pure \& Applied Bioscience, 2(3), 185-202.

Ukpaka, C. P. \& Nkakini, S.O. (2017). Crude Oil Remediation using Matlab Integrated Agricultural Best Management Practice to Improved Soil Nutrients, Petroleum \& Petrochemical Engineering Journal, 1(1), 101-106.

Ukpaka, C.P. \& Edwin, I. (2013). Adsorbent in bioremediation of crude oil Polluted Environment: Influence of Physicochemical Characteristics of Various Saw Dusts, International Research Journal of Biotechnology, 4(7), 124-141. 
Ukpaka, C.P. (2016). Development of Model for Bioremediation of Crude Oil using Moringa Extract, Chemistry International, 2(1), 19-28.

Umeda, U., Puyate, Y.T., Dagde, K.K. \& Ehirim, E.O. (2017). Effect of Oxygen Diffusion on Physicochemical Properties of Petroleum Contaminated Sandy Soil, International Journal of Agriculture and Earth Science, 3(7), 1-9.

Umeda, U., Puyate, Y.T., Dagde, K.K. \& Ehirim, E.O. (2018). Development of Predictive Model for Diffusion of Oxygen through Petroleum Contaminated Soils at 100cm Depth, International Journal of Engineering and Modern Technology, 4(2), 42-53.

Umeda, U., Puyate, Y.T., Dagde, K.K. \& Ehirim, E.O. (2018). Development of Predictive Model for Diffusion of Oxygen through Petroleum Contaminated Soils at $100 \mathrm{~cm}$ Depth, International Journal of Engineering and Modern Technology, 4(2), 42-53.

Youdeowei, P. O. (2012). Fate of Subsurface Migration of Crude Oil Spill: A Review, Crude Oil Exploration in the World, Retrieved from: http://www.intechopen.com/books/crudeoil-exploration-in-the-world/fate-of-subsurface-migration-of-crude-oilspill-a-review $24^{\text {th }}$ December, 2018.

Yuniati, M.D. (2018). Bioremediation of Petroleum-Contaminated Soil: A Review, IOP Conference Series: Earth and Environmental Science, 118. Retrieved from: http://doi:10.1088/1755-1315/118/1/012063 $18^{\text {th }}$ January, 2019. 